\title{
OPEN Author Correction: Multi-layer adaptation of group coordination in musical ensembles
}

\section{Pauline M. Hilt $\mathbb{D}$, Leonardo Badino, Alessandro D’Ausilio, Gualtiero Volpe, Serâ Tokay, Luciano Fadiga \& Antonio Camurri}

Correction to: Scientific Reports https://doi.org/10.1038/s41598-019-42395-4, published online 10 April 2019

The original version of this Article contained errors in the names of the authors Pauline M Hilt, Leonardo Badino, Alessandro D’Ausilio, Gualtiero Volpe, Serâ Tokay, Luciano Fadiga, Antonio Camurri which were incorrectly given as Hilt Pauline M, Badino Leonardo, D’Ausilio Alessandro, Volpe Gualtiero, Tokay Serâ, Fadiga Luciano, and Camurri Antonio

In addition, this Article contained errors in the Acknowledgements section.

“This work was supported by Min. Salute Ric. Finalizzata 2016 - Giovani Ricercatori to AD; POETICON++ FP7-ICT-288382 and EnTimeMent H2020-FETPROACT-824160 to LF."

now reads:

“This work was supported by Min. Salute Ric. Finalizzata 2016 - Giovani Ricercatori to AD; POETICON++ FP7-ICT-288382 to LF; SIEMPRE FP7-ICT-250026 and EnTimeMent H2020-FETPROACT-824160 to AC and LF."

These errors have now been corrected in the HTML and PDF versions of the Article, and in the accompanying Supplementary Material.

(c) (i) Open Access This article is licensed under a Creative Commons Attribution 4.0 International License, which permits use, sharing, adaptation, distribution and reproduction in any medium or format, as long as you give appropriate credit to the original author(s) and the source, provide a link to the Creative Commons license, and indicate if changes were made. The images or other third party material in this article are included in the article's Creative Commons license, unless indicated otherwise in a credit line to the material. If material is not included in the article's Creative Commons license and your intended use is not permitted by statutory regulation or exceeds the permitted use, you will need to obtain permission directly from the copyright holder. To view a copy of this license, visit http://creativecommons.org/licenses/by/4.0/.

(C) The Author(s) 2020 